\title{
The Effects Of Ultimate Controlling Shareholders On Debt Maturity Structure
}

Kun Su, Northwestern Polytechnical University, Xian, China Peng Li, Zhejiang Gongshang University, Hangzhou, China

\begin{abstract}
Using a balanced panel data of 915 Chinese listed firms, this paper studies the effect of ultimate controlling shareholders on debt maturity structure by adopting random effect model. Our results show: the larger the ultimate controlling shareholders' cash flow rights, the higher the cost of expropriating outside investors by ultimate controlling shareholder, and can reduce the agency costs of debt financing, so banks are willing to provide more long term debt funds for the firms. Ultimate controlling shareholders' cash flow rights are positively related to debt maturity structure. The larger the divergence between ultimate controlling shareholders' control rights and cash flow rights, the more likely of ultimate controlling shareholder to expropriate outside investors, and this increase the agency conflicts between firms and creditor, which leading to higher agency costs of debt financing, so banks tend to provide more short term funds for firms to constrain the ultimate controlling shareholder. The divergence between ultimate controlling shareholders' controlling rights and cash flow rights are negatively related to debt maturity structure.
\end{abstract}

Keywords: Ultimate Controlling Shareholder; Cash Flow Right; Debt Maturity Structure

\section{INTRODUCTION}

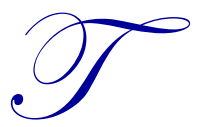

here are two important issues in corporate financing decisions. One is the capital structure issue-the choice between debt and equity capital, and the other is the debt maturity structure issue - the choice of debt financing maturity. However, previous studies focused on capital structure issue, ignoring the debt maturity structure issue. Since 1990s, with the development of corporate governance theory, many scholars show that corporate governance is an important factor in the choice of debt maturity structure (Arslan and Karan, 2006; Cai, Fairchild and Guney, 2008; Garcia-Teruel and Martinez-Solano, 2010). Recently, many studies examine the expropriation behaviors of minority shareholders arising from the perspective of ultimate controller's separation of control rights and cash flow rights (La port et al., 1999; Claessens, Djankov and Lang, 2000; Claessens et al., 2002). In this way, the focus of corporate governance is the agency problem among ultimate controller and minority shareholders (principal-principal conflicts) (La porta et al, 1999; Claessens et al, 2002; Bozec and Laurin, 2008; Hughes, 2009; Renders and Gaeremynck, 2012). Many studies also examine the universal existence of ultimate controlling shareholders in Chinese listed companies (Fan, Wong and Zhang, 2005; Liu and Sun, 2010). The ultimate controller has enormous power in influencing corporate policy (Liu and Sun, 2010), especially in financing decision (Du and Dai, 2005 ; Bany-Ariffin, Mat and McGowan, 2010). However, the focus of previous literatures on the relationship between ultimate controller and corporate financing is the capital structure decision (Bunkanwanicha, Gupta and Rokhim, 2008; Bany-Ariffin, Mat and McGowan, 2010; Liu, Tian and Wang, 2012). Little research has been done on the relationship between debt maturity structure decision and ultimate controller (Shyu and Lee, 2009). So, this paper investigates the effects of ultimate controlling shareholders on debt maturity structure in Chinese listed companies.

\section{THEORETICAL ANALYSIS AND HYPOTHESES}

Under the background of the existence of ultimate controller, ultimate controlling shareholders have motivation in supervising the manager, alleviating the agency problem, promoting the companies to adopt correct corporate policies and enhance corporate value, that is, ultimate controlling shareholders have the "incentive effect" 
to the controlled companies; While on the other side, ultimate controlling shareholders also have motivation in expropriating company resources and minority shareholders' benefits and reaping private benefits, that is, ultimate controlling shareholders also have the "entrenchment effect" to the controlled companies (Shleifer and Vishny, 1997; Claessens et al, 2002; Bozec and Laurin, 2008; Hughes, 2009). Ultimate controlling shareholders have "incentive effect" and "entrenchment effect" at the same time (Su, Yang and Yang), which make them have double motivation in influencing company debt maturity structure. Many studies show that cash flow rights represent the ultimate controlling shareholders' "incentive effect", and the separation of the control rights and cash flow rights represent the ultimate controlling shareholders' "entrenchment effect" (Yeh, 2005). The divergence between small cash flow rights and large controlling rights makes ultimate controlling shareholders have strong motivation in expropriating corporate resources and benefits, exacerbating agency problems (Claessens et al, 2002; Bozec and Laurin, 2008). The cash flow rights are a cost constraint to ultimate controlling shareholders in expropriating corporate resources. The large cash flow rights can be seen a promise signal of ultimate controlling shareholders in alleviating their agency problem and improving corporate governance level (Gomes, 2000). And on the other side, debts with different maturities have different corporate governance effect. Compared to long-term debts, short-term debts are easier to impel companies to regularly provide their operation and financial information to creditors (Rajan and Winton, 1995; DeAngelo and Wruck, 2002; Diamond and Rajan, 2001). Therefore, short-term debts are more convenient to constrain the company's opportunism behaviors (Rajan, 1992; Shyu and Lee, 2009), and short-term debts have better corporate governance effects than long-term debts. Combining the ultimate controlling shareholders' agency problems, corporate governance level and governance effect of debt maturity structure, this paper reckoned that the larger the divergence between ultimate controlling shareholders' control rights and cash flow rights, the more likely of ultimate controlling shareholders to expropriate outside investors, and the higher agency cost of debt financing, so banks tend to provide more short term funds instead of long term debt funds to companies to decrease the agency costs and constrain the ultimate controlling shareholders' expropriate behaviors to creditors. The divergence between ultimate controlling shareholders' controlling rights and cash flow rights is negatively related to debt maturity structure. On the contrary, the larger the ultimate controlling shareholders' cash flow rights, the higher costs for ultimate controlling shareholders to expropriate outside investors which decrease the probability to expropriate creditors and agency costs of debt financing, and the ultra-less fear of banks to provide long term credit for companies. The ultimate controlling shareholders' cash flow rights are positively related to corporate debt maturity structure. Base on the above basis, we proposed the following hypotheses:

H1: The ultimate controlling shareholders' cash flow rights are positively related to corporate debt maturity structure.

H2: The separation of ultimate controlling shareholders' control rights and cash flow rights are negatively related to corporate debt maturity structure.

\section{METHODS}

\subsection{Data Collection And Sample}

All the listed companies in Shanghai and Shenzhen Stock Exchange market are selected as our original samples over the period of 2004-2009. They were excluded from our sample if they are: (1) companies in Financial industry (considering the special financing characteristics of these firms); (2) ST, PT companies, since they are always related with abnormal financial situations. (3) companies in which the ultimate controlling shareholders' controlling rights are less than $10 \%$; The cutoff of $10 \%$ or $20 \%$ is conventionally used in the literatures (La Porta et al., 1999; Claessens et al., 2002). And most countries take 10\% cutoff as the lowest bound of the control right under compulsory disclosure (Du and Dai, 2005). Thus, this paper chooses $10 \%$ as the cutoff. (4) companies with extreme variable values, like those with debt ratio either greater than 1 or smaller than 0 , and those with return on assets either greater than 1 or smaller than -1; (5) companies with uncompleted data. We finally get a balanced panel data of 915 Chinese listed firms over the period 2004 to 2009(5490 observations in total). The data of ultimate controlling shareholder are manually collected from the annual report of listed companies, and other data in this paper come from CSMAR (China Stock Market Trading Research Database), which is used extensively in China. 


\subsection{Measures}

\subsubsection{Dependent Measure}

Debt maturity structure is the proportion of firms' debts with different maturities. Limited to the acquired data, based on the previous research, in the paper the ratio of long term debt to total debt is adopted to measure debt maturity structure(Arclay and Smith, 1995; Stohs and Mauer, 1995; Scherr and Hulburt, 2001; Marchica, 2007).

\subsubsection{Independent Measures}

Based on the above theoretical analysis, independent variables in this paper include ultimate controlling shareholders' cash flow rights, control rights and the separation degree of control rights and cash flow rights. According to La Porta et al (1999), cash flow right is the right to share the target company's revenue, and it is determined by the capital invested in the target company. Ultimate controller's cash flow right is computed as the cumulative percentage of ownership on the chain. In every chain, the percentage of ownership at the top node equals to the product of percentages of ownership in each layer. Control right of the ultimate controller is the sum of the weakest voting right of every layer. Let $\mathrm{Si}$ denote the fraction of the shares owned by ultimate controller in each layer on the chain of control, then the ultimate controller's control right is represented by $\sum[\min (\mathrm{S} 1, \mathrm{~S} 2, \cdots \mathrm{Sn})]$, and the cash flow right is calculated by $\sum\left(\prod S_{i}\right)$. The separation of control rights and cash flow rights refers to the case in which the control right exceeds the cash flow rights for the ultimate controller. For the sake of robustness, this paper adopts the following three variables as the measurement of separation simultaneously. Dummy variable $D I V_{l}$, representing whether there is a divergence between control right and cash flow right, which equals to 1 when control right is larger than cash flow right, and 0 otherwise; The absolute degree of separation is captured by the difference between control right and cash flow right of ultimate controller; and the relative degree of separation is captured by the ratio of the two rights' difference to control right.

\subsubsection{Other Measures}

Because corporate debt maturity structure is affected by many factors, we introduce the following control variables on the basis of previous studies: firm size (SIZE), asset maturity structure (AM), growth (TOB), profitability (ROA), capital structure (LEV), and ownership type (STATE). Meanwhile, the industry influences are further controlled in the paper. According to the "industry classification standard" issued by China Securities Regulatory Commission in 2001, listed companies could be categorized into 13 broad industries, and this paper further classify the manufacturing industry(a predominant of the listed companies) into 10 subcategories. In addition, since financial industry is not included in our samples, there are 21 industries in total in this paper. Agriculture, forest, fishing and hunting industry is set as the benchmark, with 20 industry dummy variables to represent the other 20 industries. The definitions of variables are summarized in Table 1:

Table 1: Definitions of Variables

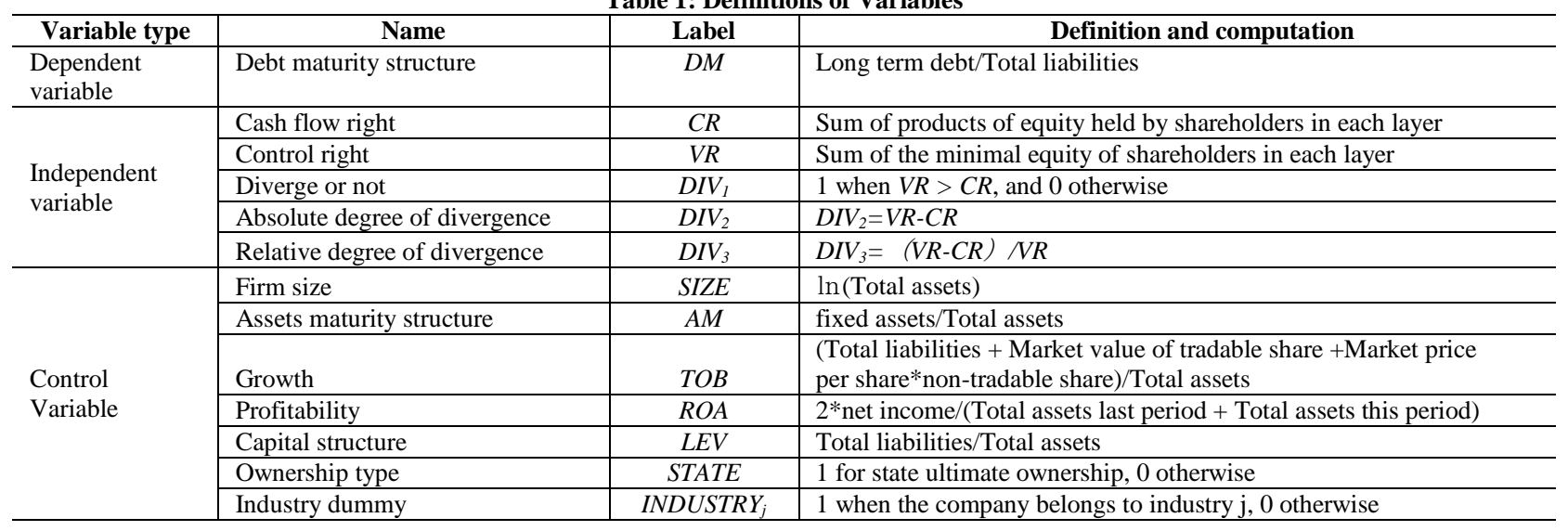




\subsection{Regression Model}

To test those hypotheses proposed above, we adopt the following random effect regression analysis model. Because of the difference in time sequences in firms, fixed effect model cannot satisfy the basic hypothesis that the effect of independent variable on dependent variable is not changed with the difference of firm and time.

$$
\begin{aligned}
D M_{i t}= & \alpha_{0}+\beta_{1} X_{i t}+\beta_{2} S_{I Z E_{i t}+\beta_{3} A M_{i t}+\beta_{4} T O B_{i t}+\beta_{5} R O A_{i t}} \\
& +\beta_{6} L E V_{i t}+\beta_{7} S_{T A T E}+\sum_{\mathrm{j}=1}^{20} \beta_{\left(7+{ }_{j}\right)} I_{N D U S T R Y_{j i t}+u_{\mathrm{i}}+\varepsilon_{\mathrm{it}}}
\end{aligned}
$$

Where $X_{i t}$ represent the variable of ultimate controlling shareholders' cash flow rights and the three variables that measure divergence of control rights and cash flow rights, respectively; and $\alpha$ represents the intercept item. The subscript $\mathrm{i}$ and $\mathrm{t}$ represent the firm and time respectively. $\mathrm{u}_{i}$ denotes the random disturb item, $\varepsilon$ denotes the random error term.

\section{EMPIRICAL RESEARCH}

\subsection{Descriptive Statistics Analysis}

Table 2 provides the descriptive statistics results of main variables for the sample. Long term debt records overall mean of $14.45 \%$, implying that companies overall enjoy a relatively low long term debt level. The listed companies mainly depend on short term debt financing. Average ultimate controlling shareholders' cash flow right is $33.55 \%$, while average control right is $39.36 \%$, indicating certain extent divergence between control rights and cash flow rights of the ultimate controlling shareholder. Specifically, around $43.77 \%$ of the companies display a separation of control rights and cash flow rights of ultimate controlling shareholders, and the mean value is $5.81 \%$ for absolute divergence and $16.96 \%$ for relative divergence between the two rights, and average the return on asset is $4.16 \%$, indicating that Chinese listed companies have a relatively low profitability. The debt ratio level records a minimum value of $0.81 \%$, maximum value of $95.69 \%$, with overall mean of $48.92 \%$, implying that companies overall enjoy a relatively middle debt ratio level. And there are great differences in assets size, assets maturity structure and growth for different companies. About $72 \%$ of our sample is state-owned companies.

Table 2: Descriptive Statistics

\begin{tabular}{lllllll}
\hline Variable & Obs. & Min. & Max. & Mean & SD. & Var. \\
\hline$D M$ & 5490 & 0.0000 & 0.9476 & 0.1445 & 0.1784 & 0.0318 \\
$C R$ & 5490 & 0.0050 & 0.9200 & 0.3355 & 0.1761 & 0.0310 \\
$V R$ & 5490 & 0.1000 & 0.9200 & 0.3936 & 0.1533 & 0.0235 \\
$D I V_{I}$ & 5490 & 0.0000 & 1.0000 & 0.4377 & 0.4961 & 0.2462 \\
$D I V_{2}$ & 5490 & 0.0000 & 0.4235 & 0.0581 & 0.0853 & 0.0073 \\
$D I V_{3}$ & 5490 & 0.0000 & 0.9793 & 0.1696 & 0.2454 & 0.0602 \\
SIZE & 5490 & 18.6160 & 27.4877 & 21.6391 & 1.0792 & 1.1648 \\
$A M$ & 5490 & 0.0010 & 0.9564 & 0.3051 & 0.1860 & 0.0346 \\
$T O B$ & 5490 & 0.7341 & 11.3571 & 1.6195 & 0.9214 & 0.8490 \\
ROA & 5490 & -0.9986 & 0.4660 & 0.0416 & 0.0607 & 0.0037 \\
LEV & 5490 & 0.0081 & 0.9569 & 0.4892 & 0.1752 & 0.0307 \\
STATE & 5490 & 0.0000 & 1.0000 & 0.7200 & 0.4490 & 0.2016 \\
\hline
\end{tabular}

\subsection{Correlation Analysis}

Pearson correlation coefficients of all variables are shown in Table 3. From the table, we can see that the ultimate controlling shareholders' cash flow rights are positively related to debt maturity structure and the coefficient is significant at the level of $1 \%$. And the three variables used to measure the divergence between ultimate controlling shareholders' controlling rights and cash flow rights are significantly negatively related to debt maturity structure, which are consistent with the theoretical analysis of Hypothesis 1 and Hypothesis 2. Other control variables and corporate debt maturity structure also have significant relationships. 


\begin{tabular}{|c|c|c|c|c|c|c|c|c|c|c|}
\hline & $D M$ & $C R$ & $D I V_{1}$ & $\mathrm{DIV}_{2}$ & $\mathrm{DIV}_{3}$ & SIZE & $A M$ & $T O B$ & $R O A$ & $L E V$ \\
\hline$\overline{D M}$ & 1.0000 & & & & & & & & & \\
\hline$C R$ & $0.1034 * * *$ & 1.0000 & & & & & & & & \\
\hline$D I V_{l}$ & $-0.0668 * * *$ & $-0.5181 * * *$ & 1.0000 & & & & & & & \\
\hline$D I V_{2}$ & $-0.0594 * * *$ & $-0.4918 * * *$ & $0.7713 * * *$ & 1.0000 & & & & & & \\
\hline $\mathrm{DIV}_{3}$ & $-0.0683 * * *$ & $-0.6388 * * *$ & $0.7837 * * *$ & $0.9026^{* * * *}$ & 1.0000 & & & & & \\
\hline$S I Z E$ & $0.3403 * * *$ & $0.2263 * * *$ & $-0.0562 * * *$ & -0.0150 & $-0.0660 * * *$ & 1.0000 & & & & \\
\hline$A M$ & $0.3074 * * *$ & $0.0870 * * *$ & $-0.0816 * * *$ & -0.0220 & $-0.0393 * * *$ & $0.1263 * * *$ & 1.0000 & & & \\
\hline TOB & $-0.1205^{*} * *$ & $-0.1110 * * *$ & $0.0531 * * *$ & 0.0021 & 0.0220 & $-0.1410 * * *$ & $-0.1231 * * *$ & 1.0000 & & \\
\hline$R O A$ & $0.0230 *$ & $0.1019 * * *$ & 0.0034 & $0.0272^{* *}$ & -0.0091 & $0.1354 * * *$ & $-0.0388 * * *$ & $0.2760 * * *$ & 1.0000 & \\
\hline$L E V$ & $0.1914 * * *$ & $-0.0534 * * *$ & -0.0036 & 0.0054 & 0.0117 & $0.3340 * * *$ & -0.0051 & $-0.2237 * * *$ & $-0.3157 * * *$ & 1.0000 \\
\hline STATE & $0.1105 * * *$ & 0.3916 *** & $-0.4402 * * *$ & $-0.3137 * * *$ & $-0.4004 * * *$ & $0.1924 * * *$ & $0.1593 * * *$ & $-0.1058 * * *$ & $-0.0471 * * *$ & $0.0399 * * *$ \\
\hline
\end{tabular}

Note; $*$, **, *** represent significant at the $10 \%, 5 \%$, and $1 \%$ level respectively.

\subsection{Multiple Regression Analysis}

On the basis of the previous research, using random effect method to further analyze the hypotheses, and the regression results are presented in Table 4. Wald value for each model is significant at the level of $1 \%$, which shows all the models fit the data relatively well.

Column (1) in Table 4 reports that after controlling other factors that might affect corporate debt maturity structure, the ultimate controlling shareholders' cash flow rights are positively related to corporate debt maturity structure, and the coefficient is significant at the level of 5\%. So hypothesis 1 holds. This shows that the larger the ultimate controlling shareholders' cash flow rights, the higher the cost for ultimate controlling shareholders to expropriate outside investors, and decrease the probability of expropriating creditors and reduce the agency costs of debt financing, so banks are willing to provide more long term debt funds for firms. The larger the ultimate controlling shareholders' cash flow rights, the longer the corporate debt maturity structure. Columns (2) to (4) shows that after controlling other factors that might affect corporate debt maturity structure, the three variables that measure divergence between ultimate controlling shareholders' control rights and cash flow rights are significantly negatively related to corporate debt maturity structure. Hypothesis 2 is supported. The larger the divergence between ultimate controlling shareholders' control rights and cash flow rights, the more likely of ultimate controlling shareholders to expropriate outside investors, and this increase the agency conflicts between firms and creditors, which leads to a higher agency cost of debt financing, and short term debt are more probably to constrain firm's opportunism behavior compared to long term debt. So to reduce the risk, banks tend to provide more short term funds for firms with large divergence between ultimate controlling shareholders' control rights and cash flow rights to constrain the ultimate controlling shareholder. The larger the divergence between ultimate controlling shareholders' control rights and cash flow rights, the shorter the corporate debt maturity structure.

Based on the analysis of control variables in Tables 4, we generate the following statements: firm size is significantly positively related to debt maturity structure. It means that the larger size of the firms, the greater ability to make long term debt financing. Assets maturity structure also displays a significantly positive relationship with debt maturity structure. This shows that the larger proportion of the fixed assets, the greater ability to make long term debt financing. Growth is significantly negatively related to debt maturity structure. It implies that the higher the growth of the firms, the higher of the risk, and banks are less likely to provide long term funds for therm. Profitability is significantly positively related to debt maturity structure, which means that the greater profitability, the greater ability to make long term debt financing. Capital structure is significantly positively related to debt maturity structure. It shows that the higher overall debt level, the larger proportion of the long term debts. Corporate debt maturity structures have no significant difference in firms of different ownership type, but have great differences among different industries. 
Table 4: Regression Results

\begin{tabular}{|c|c|c|c|c|}
\hline \multirow{2}{*}{ Variable } & \multicolumn{4}{|c|}{$D M$} \\
\hline & (1) & (2) & (3) & (4) \\
\hline \multirow{2}{*}{ Constant } & $-0.7279 * * *$ & $-0.7231 * * *$ & $-0.7232 * * *$ & $-0.7193 * * *$ \\
\hline & $(-11.1009)$ & $(-11.0347)$ & $(-11.0403)$ & $(-10.9734)$ \\
\hline \multirow{2}{*}{$C R$} & $0.0358 * *$ & & & \\
\hline & $(2.2272)$ & & & \\
\hline \multirow{2}{*}{$D I V_{l}$} & & $-0.0099^{*}$ & & \\
\hline & & $(-1.7679)$ & & \\
\hline \multirow{2}{*}{$D I V_{2}$} & & & $-0.0677 * *$ & \\
\hline & & & $(-2.1075)$ & \\
\hline \multirow{2}{*}{$D I V_{3}$} & & & & $-0.0228 * *$ \\
\hline & & & & $(-1.9858)$ \\
\hline \multirow{2}{*}{ SIZE } & $0.0345^{* * *}$ & $0.0351 * * *$ & $0.0351 * * *$ & $0.0350 * * *$ \\
\hline & $(11.4931)$ & (11.7020) & (11.7009) & (11.6559) \\
\hline \multirow{2}{*}{$A M$} & $0.0521 * * *$ & $0.0520 * * *$ & $0.0523 * * *$ & $0.0524 * * *$ \\
\hline & (3.4116) & (3.4063) & (3.4221) & $(3.4285)$ \\
\hline \multirow{2}{*}{ ТОВ } & $-0.0059 * * *$ & $-0.0065 * * *$ & $-0.0067 * * *$ & $-0.0066^{* * * *}$ \\
\hline & $(-3.1460)$ & $(-3.4945)$ & $(-3.6023)$ & $(-3.5447)$ \\
\hline \multirow{2}{*}{$R O A$} & $0.0812 * *$ & $0.0851 * *$ & $0.0862 * *$ & $0.0849 * *$ \\
\hline & (2.4183) & $(2.5400)$ & $(2.5753)$ & $(2.5343)$ \\
\hline \multirow{2}{*}{$L E V$} & $0.1849 * * *$ & $0,1830 * * *$ & $0.1836^{* * *}$ & $0.1834 * * *$ \\
\hline & (11.3497) & $(11.2525)$ & (11.2859) & (11.2771) \\
\hline \multirow{2}{*}{ STATE } & -0.0078 & -0.0082 & -0.0073 & -0.0080 \\
\hline & $(-1.0596)$ & $(-1.0770)$ & $(-0.9903)$ & $(-1.0726)$ \\
\hline INDUSTRY & Controlled & Controlled & Controlled & Controlled \\
\hline Within $R^{2}$ & 0.0685 & 0.0676 & 0.0675 & 0.0676 \\
\hline Between $R^{2}$ & 0.4429 & 0.4443 & 0.4453 & 0.4447 \\
\hline Overall $R^{2}$ & 0.3318 & 0.3325 & 0.3332 & 0.3328 \\
\hline Wald 值 & $1063.79 * * *$ & $1062.26 * * *$ & $1064.47 * * *$ & $1063.40^{* * *}$ \\
\hline 样本量 & 5490 & 5490 & 5490 & 5490 \\
\hline
\end{tabular}

Note : *, **, *** represent significant at the $10 \%, 5 \%$ and $1 \%$ level, respectively.

\section{CONCLUSION}

Under the background of the universal existence of the ultimate controlling shareholders in Chinese listed companies, using a balanced panel data of 915 Chinese listed companies over the period of 2004 to 2009 as the sample, from the perspective of ultimate ownership, this paper further analyzed the effect of ultimate controlling shareholders on corporate debt maturity structure by adopting random effect model. Results show that the proportion of the short term debt in Chinese listed firms' debt financing is very large and the proportion of long term debt is relatively low; ultimate controlling shareholders have important effects on corporate debt maturity structure. The larger the ultimate controlling shareholders' cash flow rights, the higher the cost of expropriating outside investors by ultimate controlling shareholder, and can reduce the agency costs of debt financing, so banks are willing to provide more long term debt funds for the firms. Ultimate controlling shareholders' cash flow rights are positively related to debt maturity structure. The larger the divergence between ultimate controlling shareholders' controlling rights and cash flow rights, the more likely of ultimate controlling shareholder to expropriate outside investors, and this increase the agency conflicts between firms and creditor, which leading to a higher agency costs of debt financing, so banks tend to provide more short term funds for firms to constrain the ultimate controlling shareholder. The divergence between ultimate controlling shareholders' controlling rights and cash flow rights is negatively related to debt maturity structure. The study has great significance in improving ultimate controlling shareholders' governance behavior and in optimizing corporate debt maturity structure. 


\section{ACKNOWLEDGEMENTS}

This research was partially supported by the Soft Science Project of Shaanxi Province, Development Fund of Social Science and Management in Northwestern Polytechnical University (RW201203) and the Research Start-up project of Northwestern Polytechnical University (11GH0313).

\section{AUTHOR INFORMATION}

Dr. Kun Su is an assistant professor of accounting in the School of Management at Northwestern Polytechnical University. His main research interests include corporate governance, financial disclosure, and corporate finance. E-mail: suk711@126.com (Corresponding author)

Dr.Peng $\mathbf{L i}$ is an assistant professor of accounting in the School of Accounting at Zhejiang Gongshang University. His main research interests include corporate governance and accounting information disclosure. E-mail: lpruc@yahoo.cn

\section{REFERENCES}

1. Arslan O, Karan M.B. (2006). Ownership and control structure as determinants of corporate debt maturity: a panel study of an emerging market. Corporate Governance: An International Review, 14 (4): 312-324.

2. Bany-Ariffin AN, Mat Nor F, McGowan Jr CB. (2010). Pyramidal structure, firm capital structure exploitation and ultimate owners' dominance. International Review of Financial Analysis, 19 (3): 151-164.

3. Bozec Y, Laurin C. (2008). Large Shareholder Entrenchment and Performance: Empirical Evidence from Canada. Journal of Business Finance \& Accounting, 35 (1-2): 25-49.

4. Bunkanwanicha P, Gupta J, Rokhim R. (2008). Debt and Entrenchment: Evidence from Thailand and Indonesia. European Journal of Operational Research, 185 (3): 1578-1595.

5. Cai K, Fairchild R, Guney Y. (2008). Debt maturity structure of Chinese companies. Pacific-Basin Finance Journal, (16): 268-297.

6. Claessens S, Djankov S, Lang, L.H.P.(2000). The Separation of Ownership and Control in East Asian Corporations. Journal of Financial Economics, (58):81-112.

7. Claessens,S, Djankov, S, FAN, J and Lang, L.H.P. (2002). Disentangling the incentive and entrenchment effects of large shareholdings. Journal of Finance, 57(6):2741-2771

8. DeAngelo H, Wruck K (2002). Asset liquidity, debtcovenants, and managerial discretion in financial distress: the collapse of L.A.Gear. Journal of Financial Economics, 64(1):3-34.

9. Diamond D, Rajan R. (2001). Banks, short term debt and financial crises: theory, policy implications and applications. Carnegie-Rochester Conference Series on Public Policy, 54: 37-71.

10. Du J, Dai Y. (2005). Ultimate Corporate Ownership Structures and Capital Structures: Evidence from East Asian Economies. Corporate Governance: An International Review, 13 (1): 60-71.

11. Fan,Joseph P.H., T. J.Wong and Tianyu Zhang (2005). The emergence of Corporate Pyramids in China. The Chinese University of Hong Kong.

12. Garcia-Teruel P, Martinez-Solano P (2010). Ownership structure and debt maturity: new evidence from Spain. Review of Quantitative Finance and Accounting, 35 (3): 473-491.

13. Gomes., A.. (2000). Going public without governance: managerial reputation effects. Journal of Finance, 55(2):615-646

14. Guedes J., Opler T. (1996). The determinants of the maturity of corporate debt issues. Journal of Finance, 51 (5): 1809-1833.

15. Hughes P. (2009). Corporate Value, Ultimate Control and Law Protection for Investors in Western Europe. Management Accounting Research, 20 (1): 41-52.

16. La Porta R, Lopez-De-Silanes F, Shleifer A. (1999). Corporate ownership around the world. Journal of Finance, (54):471-517.

17. Liu G, Sun J. (2010). Ultimate Ownership Structure and Corporate Disclosure Quality: Evidence from China. Managerial Finance, 36(5):452-467.

18. Liu Q, Tian G, Wang X. (2012). Controlling shareholder, expropriations and firms leverage decision: evidence from Chinese Non-tradable share reform. Journal of Corporate finance, 18 (3): 782-803.

2013 The Clute Institute http://www.cluteinstitute.com/ 
19. Marchica M (2007). Debt maturity and the characteristics of ownership structure: an empirical investigation of UK firms. Paper presented at FMA annual meeting

20. Rajan R. (1992). Insiders and outsiders: the choice between informed and arm's length debt. Journal of Finance. 47 (6): 1367-1400.

21. Rajan R, Winton A. (1995). Covenants and collateral as incentives to monitor. Journal of Finance, 50(5): 1113-1146.

22. Renders A, Gaeremynck A. (2012). Corporate governance, principal-principal agency conflicts, and firm value in European listed companies. Corporate Governance: An International Review, 20 (2): 125-143.

23. Scherr F.C., Hulburt H.M. (2001). The debt maturity structure of small firms. Financial Management, 30 (1): 85-111.

24. Shleifer, A, Vishny, R. (1997). A survey of corporate governance. Journal of Finance, 52(2): 737-783

25. Shyu Y.W, Lee C. (2009). Excess control rights and debt maturity structure in family-controlled firms. Corporate Governance: An International Review, 17 (5): 611-628.

26. Stohs M.H., Mauer D.C. (1996). The determinants of corporate debt maturity structure. Journal of Business, 69 (3): 279-312.

27. Su K., Yang S, Yang B. (2010). Ultimate ownership and firm performance: evidence from Chinese privated listed firms. International Journal of Management Science and Engineering Management, 5(3):182-191.

28. Yeh, Y. H. (2005). Do controlling shareholders enhance corporate value?. Corporate Governance, 13(2):313-325 